\title{
Increase in perennial forage yields driven by climate change, at Apukka Research Station, Rovaniemi, 1980-2017
}

\author{
Oiva Niemeläinen ${ }^{1}$, Antti Hannukkala ${ }^{2}$, Lauri Jauhiainen ${ }^{1}$, Kaija Hakala ${ }^{1}$, Markku Niskanen ${ }^{3}$ and Antti Laine ${ }^{1}$ \\ ${ }^{1}$ Natural Resources Institute Finland (Luke), Tietotie 4, FI-31600 Jokioinen, Finland \\ ${ }^{2}$ Natural Resources Institute Finland (Luke), Ounasjoentie 6, Fl-96200 Rovaniemi, Finland \\ ${ }^{3}$ Natural Resources Institute Finland (Luke), Kampusranta 9 C, FI-60320 Seinäjoki, Finland \\ e-mail: oiva.niemelainen@luke.fi
}

\begin{abstract}
The official variety trials at Rovaniemi, Finland $\left(66.58^{\circ} \mathrm{N}, 26.01^{\circ} \mathrm{E}\right)$ in $1980-2017$ show a substantial increase in dry matter yields (DMY) of timothy (Phleum pratense), meadow fescue (Festuca pratensis) and tall fescue (Festuca arundinacea), coinciding with a $156^{\circ} \mathrm{Cd}$ increase in the average growing season $\mathrm{T}_{\text {sum }}$ and a $461{ }^{\circ} \mathrm{Cd}$ decrease in the average winter frost sum for the same period. The annual DMY of timothy was $3128,4668,8385$ and $9352 \mathrm{~kg} \mathrm{ha}^{-1}$ in the periods (P) 1980-1989 (P1), 1990-1999 (P2), 2000-2009 (P3), and 2010-2017 (P4). The first cut yielded 1792, 2166,4008 and 4473 , and the second cut 1337, 2503, 4378 and $4879 \mathrm{~kg} \mathrm{ha}^{-1}$, respectively. Yields of meadow fescue followed a similar pattern. The first cut was about ten days and the second cut about one week earlier on P4 than on P1. Shorter snow cover period, milder winters, higher live ground cover of timothy in spring, and higher temperature sum during the growing season were most likely responsible for the yield increase. The results indicate a strong impact of climate change on DMY of perennial forage crops in the north.
\end{abstract}

Key words: forage production, overwintering, productivity, grassland management, timothy

\section{Introduction}

Anthropogenic emissions of greenhouse gases (GHG) are warming the atmosphere (IPCC 2013). Since the industrial revolution, the atmosphere has warmed on average by $0.8-1.2^{\circ} \mathrm{C}$ (IPCC 2018). The average temperatures increase more and faster in the north than at lower latitudes (IPCC 2013, Mikkonen et al. 2015). This has been visible e.g., around the North Pole, where unusually high temperature readings have been recorded recently (IPCC 2013, Watts 2019). Changes in climate due to the warming have been observed in all parts of the world, e.g., as severe droughts, heavy rains and flooding and long and extreme heat waves. Due to the observations of the past and present climatic changes, an effort to limit global warming to $1.5^{\circ} \mathrm{C}$ has recently been called for by the IPCC (2018).

Climate change is anticipated to have general negative impacts on agricultural production worldwide. However, in northern areas the impacts may also be positive, especially if efficient adaptation measures, such as a shift in production to different crops, or from crop production to animal husbandry, are adopted (Porter et al. 2014). In Finland, the yield potential of cereals, oilseeds and pulses is expected to increase significantly with moderate $\left(1-2{ }^{\circ} \mathrm{C}\right)$ increases in global temperatures and the resulting climate change (Peltonen-Sainio et al. 2009). The increase in production potential would be a result of more favorable growing conditions, such as a longer growing season and a higher effective temperature sum $\left(\mathrm{T}_{\text {sum }}\right)$. Even though the changes in conditions also favor pests and pathogens, adaptive measures are believed to increase the yields and income of farmers (Hakala et al. 2011). Genetic improvements (new types of crops and cultivars) are crucial, however, to gain most from the improved conditions (Peltonen-Sainio et al. 2009).

Agricultural production in Lapland is based on grassland cultivation. The 1322 farms in Finnish Lapland have 44700 ha of agricultural land of which over $90 \%$ is in grassland production, the main production types being silage ( $31500 \mathrm{ha})$, hay (4600 ha) and pasture (1100 ha) (https://stat.luke.fi/). Successful grassland production is of utmost importance for milk and meat production in Lapland. So at present, grasses are the main crop produced in Lapland province, but the production potential of cereals could also increase in the future (Peltonen-Sainio et al. 2009). The longer and warmer future growing seasons, together with long days should increase the production potential of grasses, if management measures, such as fertilization and number of cuts are adjusted to the new conditions (Hakala and Mela 1996). Even though the longer growing season and milder winters will probably have the greatest effect on the grass growth in the north, increases in the ambient $\mathrm{CO}_{2}$ concentrations may also have a positive effect. An about 300 ppm increase (from 360 to about 700 ppm) in atmospheric $\mathrm{CO}_{2}$ concentration increased the rate of photosynthesis of meadow fescue (Festuca pratensis) by 30-40 \% in open top chamber experiments in Jokioinen, Finland in 1992-1995 (Hakala et al. 1999). This resulted in an about 10\% increase in biomass in ambient temperatures 


\section{AGRICULTURAL AND FOOD SCIENCE}

O. Niemeläinen et al. (2020) 29: 139-153

and $20-30 \%$ increase in biomass, when temperatures were also increased and the cutting regime was adjusted to the growth potential to avoid canopy closure (Hakala and Mela 1996). In the same time, and especially when the above ground biomass increased only little, the weight of roots increased by 30-60\%, and the stomatal conductance of the leaves decreased by 30-40\%. A larger root system may increase the overwintering potential of the grasses in the future. Together with lower stomatal conductance, a larger root system may also help the grasses to maintain photosynthesis and biomass production for longer periods in unfavorable conditions, such as drought.

In addition to management practices, the diversity of grass species and cultivars should be kept at a high level in order to maintain response diversity of the grasslands to various future conditions, such as flooding, drought, heat waves and variations in temperature in the growing season and in winter (IPCC 2012, Mäkinen et al. 2015). A major problem in Finnish Lapland is, however, represented by winter pathogens that thrive under the thick and long-lasting snow cover, weakening and killing grasses during and after winter (Nissinen 1996).

Climate change is predicted to result in increased temperatures, especially in winter (Ruosteenoja et al. 2020), thereby shortening the snow cover period and bringing relief for the pathogen problem (Nissinen 1996). However, if the growing season lasts too long, the temperature conditions that favor accumulation of reserve carbohydrates and cold acclimation late in the season could be transferred to a period too late in the autumn. The short days and low light intensity in late autumn may challenge cold acclimation in general, as well as accumulation of reserve carbohydrates that help the grasses resist the pathogens during winter ( $\varnothing$ strem et al. 2015, Dalmannsdottir et al. 2017). This problem would be most serious in Lapland, where the changes in day length after autumn and spring equinoxes are substantial. For example, in Rovaniemi the day length drops from 11 hours (angle of sun $19.62^{\circ}$ ) in the beginning of October to just seven hours (angle of sun $8.58^{\circ}$ ) in the beginning of November (http://www. moisio.fi/taivas/aurinko.php?paikka=Rovaniemi\&dy=3\&mn=10\&yr=2019).

Because of the higher intensity of climatic change at the highest latitudes, impacts of climate change on agriculture in areas such as Finnish Lapland may be more severe and far reaching than at lower latitudes.

In this article we study how changes in climatic conditions crucial for agricultural production have affected the performance of perennial grasses during the last 40 years in the variety trial test site Apukka in Rovaniemi $\left(66.58^{\circ} \mathrm{N}\right.$, $26.01^{\circ} \mathrm{E}$ ). With the help of predictions for future climate change (Ruosteenoja et al. 2020) we discuss the effects of the future climatic conditions on agricultural production in the northernmost areas of Finland and of the world.

\section{Materials and methods}

We used the Finnish official variety trial data for timothy (Phleum pratense; TIM), meadow fescue (Festuca pratensis; MF) and tall fescue (Festuca arundinacea; TF) from Apukka, Rovaniemi $\left(66.58^{\circ} \mathrm{N}, 26.01^{\circ} \mathrm{E}\right)$ for the estimations of yield development in 1980-2017. Data for climatic conditions for the same site were obtained from the Finnish Meteorological Institute (FMI). The weather data included average daily mean temperatures, daily rainfall and snow depth. Calculated variables were length of growing season, effective $\mathrm{T}_{\text {sum }}$ (base temperature $+5^{\circ} \mathrm{C}$ ), accumulated rainfall during different periods, length of snow cover periods and frost sum during winters. Growing season starts when daily mean temperature raise above $+5{ }^{\circ} \mathrm{C}$ in five consecutive days in absence of snow, and ends when temperature decrease under $+5^{\circ} \mathrm{C}$ in five consecutive days or when snow cover appears. To study and illustrate the changes over time, the material was divided into four periods (P): 1980-1989 (P1), 1990-1999 (P2), 2000-2009 (P3), and 2010-2017 (P4).

\section{Data from grass variety trials}

The Natural Resources Institute Finland (Luke) is responsible for carrying out the official variety tests in Finland. The Apukka research station is the northernmost active experimental site. The guidelines for carrying out of perennial grass variety experiments did not change much during the study period 1980-2017. The trials were sown without a companion crop and a cleaning cut was taken in the autumn of the establishment year when necessary. The testing period in each trial lasts for three production years after the establishment year. The three-year trial period is considered necessary to show differences over the normal 3-4 year sward production period for silage production. Thus each three-year trial gives results for the first, second and third production year (altogether three results). The trials were established every second year since year 2002 and nearly annually before that. Therefore, during certain years more than one trial was carried out. For example, when first and third year experiments were 


\section{AGRICULTURAL AND FOOD SCIENCE}

O. Niemeläinen et al. (2020) 29: 139-153

carried out those years had two results in the data. Number of results for the first, second and third year stands of timothy, meadow fescue and tall fescues during study periods P1, P2, P3 and P4 are presented in Table 1. However, the timothy data include also one first year result from 1978 and 1979, and a second year result in 1979 as we wanted to include the complete three-year trial data into the study from all trials. During the whole study period (1978-2017) production data for timothy and meadow fescue were available for all years except 1995 and 1999 for timothy, and 1988 and 1999 for meadow fescue. Reasons for lack of data for those years were not related to trial performance but to factors like establishment not being carried out. Data for tall fescue is only for periods 2 , 3 and 4. Since 2002 the experiments have been established every second year, resulting in that every second year results were from the first and third year stands and every second year from second year stands.

Table 1. Number of experiments in Apukka for the $1^{\text {st }}(\mathrm{Y} 1), 2^{\text {nd }}(\mathrm{Y} 2)$ and $3^{\text {rd }}(\mathrm{Y} 3)$ year stands of timothy (TIM), meadow fescue (MF) and tall fescue (TF) in the periods 1980-1989 (P1), 1990-1999 (P2), 2000-2009 (P3), and 2010-2017 (P4)

\begin{tabular}{ccccccccccccccc}
\hline & TIM & TIM & TIM & TIM & MF & MF & MF & MF & TF & TF & TF & TF \\
\hline P1* & Y1 & Y2 & Y3 & ALL & Y1 & Y2 & Y3 & ALL & Y1 & Y2 & Y3 & ALL \\
P2 & 3 & $4 *$ & 6 & 21 & 5 & 3 & 2 & 10 & 0 & 0 & 0 & 0 \\
P3 & 5 & 5 & 4 & 14 & 5 & 5 & 4 & 14 & 2 & 2 & 1 & 5 \\
P4 & 4 & 4 & 4 & 12 & 4 & 4 & 4 & 12 & 1 & 1 & 2 & 4 \\
Total & 20 & 20 & 18 & 58 & 18 & 17 & 15 & 50 & 7 & 7 & 7 & 21 \\
\hline
\end{tabular}

*For timothy the data include one result for first year sward in 1978 and one in 1979 and one for second year result in 1979.

The number of cultivars in a trial varied among species and trials. The total number of results (result for one cultivar for one year in a trial) was highest for timothy. Timothy had 183, 169, 126 and 57 results for periods P1, P2, P3 and P4, respectively. For meadow fescue, the respective numbers were 30, 101, 86 and 48. Tall fescue was represented by only one cultivar in the testing and it was assessed within the meadow fescue trials. The number of results for tall fescue is the same as for the number of trials $0,12,5$ and 4 for the periods P1, P2, P3 and P4, respectively. The trials were harvested twice in a season. Annual nitrogen fertilizer application increased slightly

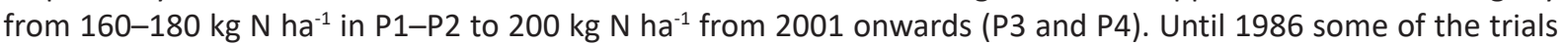
were on organic soils, but since 1986 all trials have been on mineral soil. The first cut was taken at the silage harvest stage (soon after heading). However, during P1 timothy trials were cut slightly later (at hay stage) than the meadow fescue trials (at silage stage). After P1 both timothy and fescues were cut at the same date. The guidelines for taking the second cut were to harvest the stand early enough to provide adequate time for the stand to recover from the last cut and harden before the winter. Plot size was $1.5 \mathrm{~m}$ wide and from 8 to $10 \mathrm{~m}$ long. Three or four replicates were used. The trials were harvested using a Haldrup forage harvester.

The measured characteristics included: live ground cover percentage in spring, the date for the first and the second cut and the dry matter yield $\left(\mathrm{kg} \mathrm{ha}^{-1}\right)$. The dry matter yield is based on the measured fresh yield of the plot and on dry matter percentage calculated from a representative sample (around $1 \mathrm{~kg}$ ) taken from all replicates from each cultivar and cut. The dry matter yield ha-1 is based on the yield of the sown species. Botanical analyses of representative samples were carried out if the amount of weeds was visually estimated to be over five percent of the total yield, and the pure grass yield was calculated according to the sown species in the sample. Results for the 2009-2016 testing period and information on how to interpret the results are presented in Laine et al. (2017). Current guidelines (in Finnish) to carry out official variety trials in Finland are available on request (Virallisten lajikekokeiden suoritusohjeet 2018).

\section{Statistical analyses}

The set of tested cultivars varied among trials but some control cultivars were tested for longer than ten years. To separate environmental and genotypic effects, original data were analyzed, including cultivar and trial, according to the model:

$$
\mathrm{y}_{\mathrm{ijk}}=\mu+\text { trial }_{\mathrm{ij}}+\text { cultivar }_{\mathrm{k}}+\varepsilon_{\mathrm{ijk}}
$$

in which $\mathrm{y}_{\mathrm{ijk}}$ is observed dry matter yield of kth cultivar in ith year and jth trial (if more than one trial in some years), while $\mu$ is intercept, trial ${ }_{i j}$ is the effect of trial, cultivar ${ }_{k}$ is effect of cultivar and $\varepsilon_{i j k}$ residual error. Dry matter yield of the first and second cuts were analyzed separately, as well as sum of two cuts and the ratio of the first and second cuts. Yield level varied according to age of stand, so trials with different aged stands were analyzed separately. Analysis was done using SAS/MIXED software. Resulted estimated means for each trial, were used in forthcoming 


\section{AGRICULTURAL AND FOOD SCIENCE}

O. Niemeläinen et al. (2020) 29: 139-153

analysis. Similar analysis was done for live ground cover in the spring. Statistical analysis showed that the relationship between year and response variables (e.g., live ground cover percentages in spring, DMY) were not always linear. Therefore, at the first stage the relationship was modeled using graphical methods by adding a smoothing spline curve to a scatter plot. Spline curves were calculated using SAS/GRAPH software. Despite non-linearity, at the second stage tests for linear and quadratic polynomial trends for yields and live ground cover percentages in spring resulted in statistically significant effects for slope (by using SAS/REG software to fit linear or quadratic polynomial regression model).

The linear regression model was fitted for weather data to test trends in observations for weather variables during the study period (by SAS/REG software).

\section{Results}

The results from grass trials are presented either by covering the whole study period or by categorizing them into four time periods, P1 (1980-1989), P2 (1990-1999), P3 (2000-2009) and P4 (2010-2017).

\section{Changes in climatic conditions during the study period}

Temperatures in the growing season

The mean monthly temperatures for the growing season increased from P1 to P4 in July and August, and in May there was a tendency for increase (Table 2). The beta value in the table describes how much in ${ }^{\circ} \mathrm{C}$ the temperature changed in a year during the study period. The mean monthly temperatures in May, July and August increased on average by $0.05{ }^{\circ} \mathrm{C}$ in each year (Table 2). Mean temperatures in June stayed the same during the study periods (Table 2).

Table 2. Mean monthly temperatures in May-August in the periods 1980-1989 (P1), 1990-1999 (P2), 2000-2009 (P3), and 2010-2017 (P4) and annual change during the whole study period 1980-2017 (beta)

\begin{tabular}{ccccc}
\hline Period/Month & May ${ }^{\circ} \mathrm{C}$ & June ${ }^{\circ} \mathrm{C}$ & July ${ }^{\circ} \mathrm{C}$ & August ${ }^{\circ} \mathrm{C}$ \\
\hline P1 & 6.5 & 12.5 & 14.8 & 11.4 \\
P2 & 5.1 & 12.3 & 14.8 & 12.4 \\
P3 & 6.7 & 12.6 & 15.9 & 13.2 \\
P4 & 7.6 & 12.1 & 16.2 & 13.1 \\
beta & 0.045 & -0.004 & 0.051 & 0.059 \\
SE & 0.025 & 0.025 & 0.022 & 0.018 \\
p & 0.09 & 0.86 & 0.03 & $<0.01$ \\
\hline
\end{tabular}

$\mathrm{T}_{\text {sum }}$ accumulates mainly in June, July and August in Apukka. The mean monthly $\mathrm{T}_{\text {sums }}$ for the last 40 years for May, June, July, August, September and October were 76.5, 222.2, 317.0, 231.3, 85.0 and 12.4 degree-days ( $\left.{ }^{\circ} \mathrm{Cd}\right)$, respectively. The $\mathrm{T}_{\text {sums }}$ during the growing seasons increased steadily in Apukka since 1978 (Fig. 1). The average $T_{\text {sum }}$ increased from $880^{\circ} \mathrm{Cd}$ on P1 (1980s) to $1036^{\circ} \mathrm{Cd}$ on P4 (2010s) (Table 3). Since 2010, the $\mathrm{T}_{\text {sum }}$ has been $1100^{\circ} \mathrm{Cd}$ or higher in five out of nine years (Fig. 1).

Table 3. Beginning and end (mean, earliest and latest date), length and temperature sums, degree-days, base temperature $+5^{\circ} \mathrm{C}$ $\left(T_{\text {sums }}{ }^{\circ} \mathrm{Cd}\right)$, of growing seasons in the periods 1980-1989 (P1), 1990-1999 (P2), 2000-2009 (P3) and 2010-2017 (P4). Growing season starts when daily mean temperature raise above $+5^{\circ} \mathrm{C}$ in five consecutive days in absence of snow, and ends when temperature decrease under $+5{ }^{\circ} \mathrm{C}$ in five consecutive days or when snow cover appears.

\begin{tabular}{|c|c|c|c|c|c|c|c|c|}
\hline Period & $\begin{array}{c}\text { Mean start } \\
\text { date }\end{array}$ & $\begin{array}{c}\text { Earliest } \\
\text { start date }\end{array}$ & $\begin{array}{c}\text { Latest start } \\
\text { date }\end{array}$ & $\begin{array}{l}\text { Mean end } \\
\text { date }\end{array}$ & $\begin{array}{c}\text { Earliest end } \\
\text { date }\end{array}$ & $\begin{array}{c}\text { Latest end } \\
\text { date }\end{array}$ & $\begin{array}{l}\text { Length of } \\
\text { growing } \\
\text { season (days) }\end{array}$ & $\begin{array}{c}\mathrm{T}_{\text {sum }} \\
\left({ }^{\circ} \mathrm{Cd}\right)\end{array}$ \\
\hline P2 & May 13 & Apr 25 & May 25 & Sept 25 & Sept 3 & Oct 10 & 134.1 & 859 \\
\hline P3 & May 7 & Apr 27 & May 23 & Sept 30 & Sept 17 & Oct 22 & 144.7 & 1021 \\
\hline
\end{tabular}




\section{AGRICULTURAL AND FOOD SCIENCE}

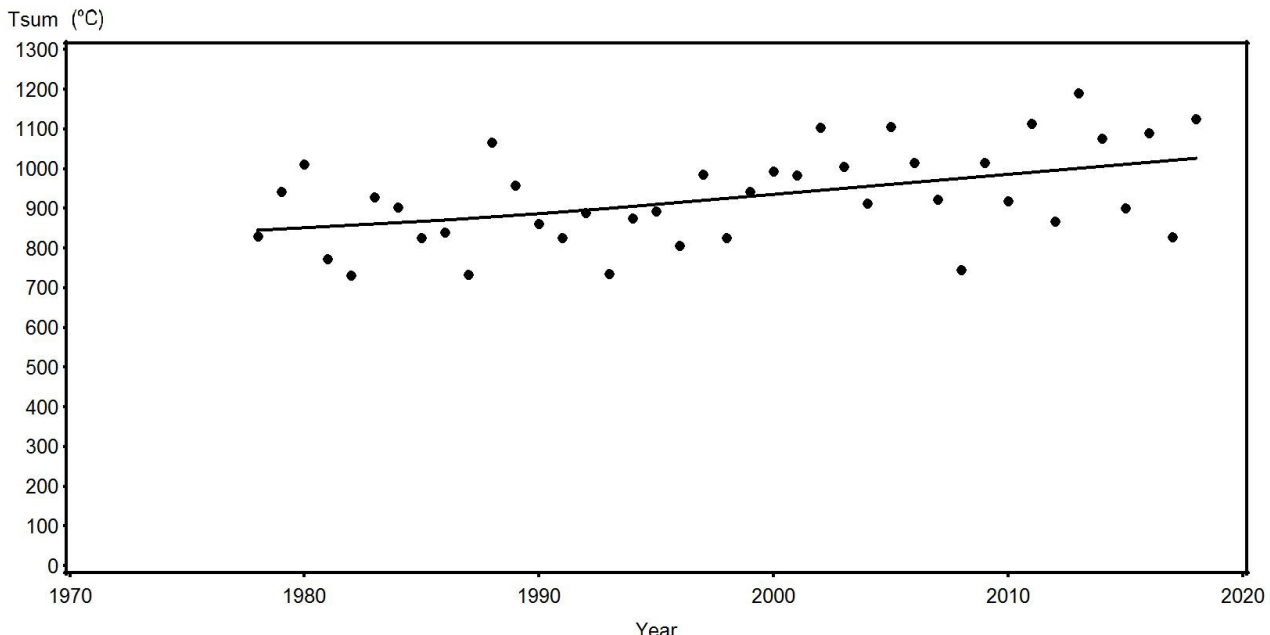

Fig. 1. Development in temperature sum, degree-days $\left(\mathrm{T}_{\text {sum }}{ }^{\circ} \mathrm{Cd}\right.$, base temperature $\left.+5^{\circ} \mathrm{C}\right)$ during the last 40 years (1978-2018)

The length of the growing season has not increased in the same way as the $T_{\text {sums }}$ during the study period (Table 3). The mean length of the growing season has ranged from 134.1 days on P2 to 144.7 days in periods P3 and P4.

\section{Precipitation}

Soil moisture is usually adequate for plant growth in Apukka, as melting snow fills up the soil water reservoirs to water-holding capacity in the spring, the growing season is short and the mean daily temperatures are relatively low. Mean rainfall in growing season (months) during periods P1-P4 is presented in Table 4. Statistical analyses showed no trend in the monthly rainfall between the periods (Table 4). In addition, we studied the duration of the longest dry periods - specified as continuous time in days with less than $2 \mathrm{~mm}$ rainfall a day - for periods P1, P2, P3 and P4. The mean values were 19.1, 25.6, 21.8, and 21.4 days, respectively.

Table 4. Mean rainfall (mm) in May-August in the periods 1980-1989 (P1), 1990-1999 (P2), 2000-2009 (P3) and $2010-2017$ (P4) and changes in monthly rainfalls during the whole study period 1980-2017. Linear regression was used to calculate average annual change. Beta is a regression coefficient for the slope.

\begin{tabular}{cllll}
\hline Period/Month & May & June & July & August \\
\hline P1 & 44.1 & 61.1 & 64.1 & 79.8 \\
P2 & 32.9 & 64.7 & 70.8 & 62.9 \\
P3 & 48.9 & 48.1 & 79.6 & 65.9 \\
P4 & 44.4 & 68.2 & 76.3 & 50.6 \\
beta & 0.28 & 0.24 & 0.12 & -0.08 \\
SE & 0.22 & 0.32 & 0.32 & 0.32 \\
$p$ & 0.21 & 0.46 & 0.79 & 0.73 \\
\hline
\end{tabular}

\section{Winter conditions}

To identify the possible changes in overwintering conditions during the study period we studied the length of the snow cover period, daily mean temperatures and frost sum during the four periods P1-P4. In Figures 2, 3 and 4 the symbols and line types show the spline interpolations produced for periods P1, P2, P3 and P4, respectively. Periods of snow cover (at least one cm of snow on the ground) started around two weeks later in P4 than in P1, and ended a few days earlier in P4 than P1 (Fig. 2). However, the variation among years was large in relation to differences in means between periods (gray lines in Fig. 2). 


\section{AGRICULTURAL AND FOOD SCIENCE}

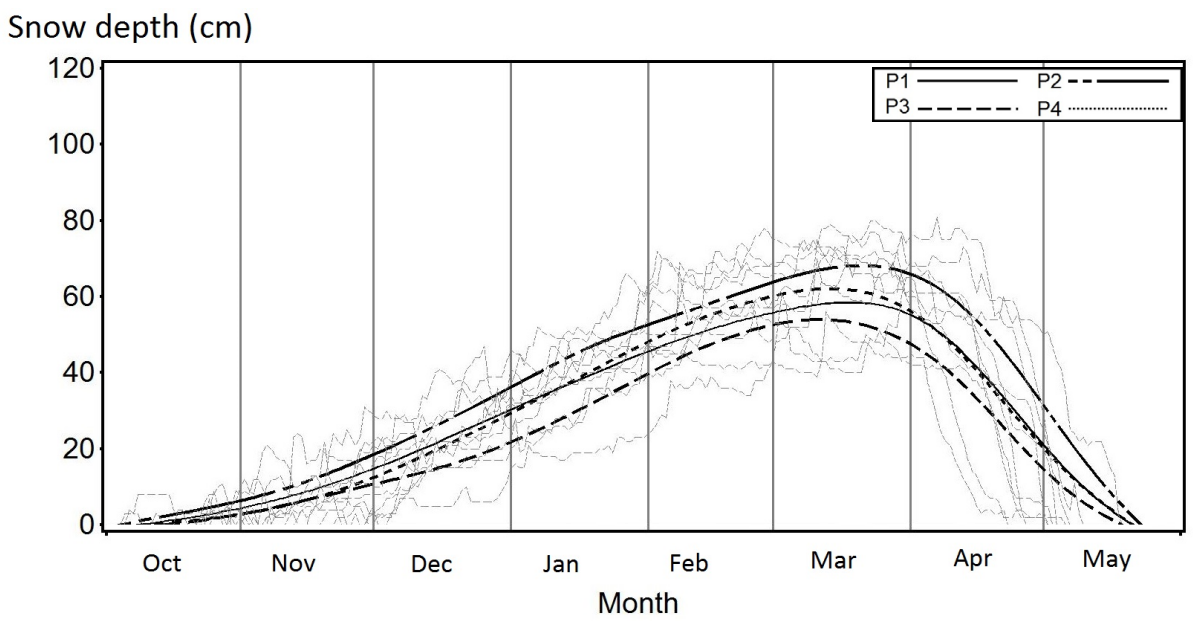

Fig. 2. Snow cover depth (cm) in October-May in winter periods 1980-1989 (P1), 1990-1999 (P2), 2000-2009 (P3) and 2010-2019 (P4). Gray lines represent yearly values in P4.

The mean daily temperatures for the different winter periods are presented in Figure 3. The results indicate warmer conditions since P1, especially in December and January (Fig. 3).

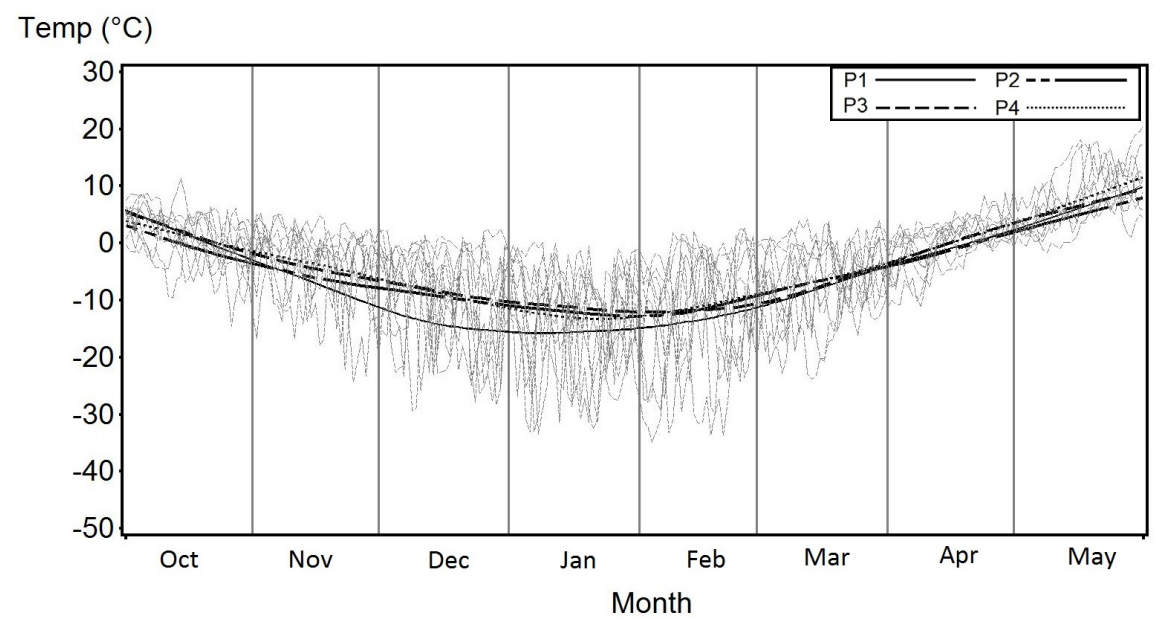

Fig. 3. The mean daily temperatures $\left({ }^{\circ} \mathrm{C}\right)$ in October-May in winter periods 1980-1989 (P1), 1990-1999 (P2), 2000-2009 (P3) and 2010-2019 (P4). Gray lines represent yearly values in P4.

The frost sum is calculated as accumulation of ${ }^{\circ} \mathrm{Cd}$ when the daily mean temperature is lower than $0.0^{\circ} \mathrm{C}$. Frost sum was on average $-1850^{\circ} \mathrm{C}$ during $\mathrm{P} 1,-1522^{\circ} \mathrm{C}$ during P2, $-1403^{\circ} \mathrm{C}$ during P3 and $-1389^{\circ} \mathrm{C}$ during P4 (Fig. 4). The mean frost sum was $461{ }^{\circ} \mathrm{Cd}$ lower during the last period (P4), than during P1.

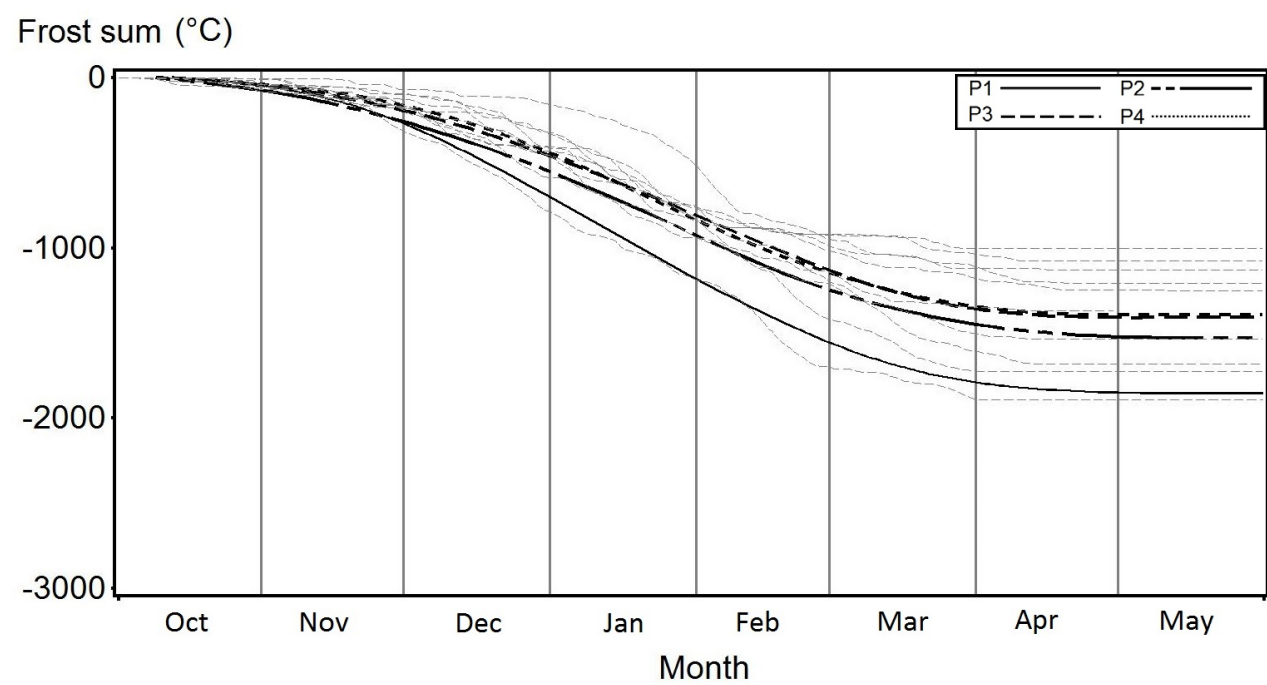

Fig. 4. The frost sum ( $\left.{ }^{\circ} \mathrm{Cd}\right)$ in October-May in winter periods 1980-1989 (P1, red line), 1990-1999 (P2, black line), 2000-2009 (P3, blue line) and 2010-2019 (P4, green line). Gray lines represent yearly values in $\mathrm{P} 4$. 


\section{Changes in grass performance during the study periods}

Live ground cover in the spring

During the first study period (P1) the mean live ground cover (LGC) percentages in the spring were $77 \%$ and $65 \%$ for timothy and meadow fescue, respectively, in the first production year, but decreased to under $30 \%$ in the second year and to under $20 \%$ in the third stand year (Table 5). The situation improved in the second period (P2), with over 60\% mean LGC in the second year for both timothy and meadow fescue. In spring of the third year, however, the LGC was only 50\% or lower (Table 5). Tall fescue, which was included in the trials from P2, had high LGC (69\%, 78\% and $82 \%$ in first, second and third year stands, respectively) in the spring already in P2. During the last period (P4) the mean LGC percentages in spring remained high (80-97\%) for all three grass species and age categories of leys (Table 5).

Table 5. Live ground cover percentages in the spring for different grasses, study periods (1980-1989 [P1], 1990-1999 [P2], 2000-2009 [P3] and 2010-2017 [P4]) and stands in $1^{\text {st }}(\mathrm{Y} 1), 2^{\text {nd }}(\mathrm{Y} 2)$ and $3^{\text {rd }}(\mathrm{Y} 3)$ production year. TIM=timothy, $\mathrm{MF}=$ meadow fescue, $\mathrm{TF}=$ tall fescue

\begin{tabular}{cccccccccc}
\hline $\begin{array}{c}\text { Period/Year and } \\
\text { species }\end{array}$ & Y1 TIM & Y2 TIM & Y3 TIM & Y1 MF & Y2 MF & Y3 MF & Y1 TF & Y2 TF & Y3 TF \\
\hline P1 & 77 & 31 & 20 & 65 & 21 & 4 & & 78 \\
P2 & 71 & 61 & 38 & 65 & 69 & 51 & 69 & 78 \\
P3 & 62 & 83 & 57 & 68 & 84 & 60 & 64 & 95 & 90 \\
P4 & 91 & 86 & 86 & 91 & 83 & 87 & 97 & 93 & 89 \\
\hline
\end{tabular}

In the P1 period, yield data were recorded also in trials with very low spring LGC percentages. In the period P2 the LGC in spring in the timothy trial for years 1992-1994 had low values in the second and third year (28\% in 1994 and 8\% in 1995). In the last period P4 the LCG percentage in spring has rarely been lower than 80\% in timothy. Also meadow fescue had low LGC percentages in spring during the periods P1 and P2. All recent trials have overwintered well, and trials have not been rejected. As the trial period was set to three years, the trials that had low LGC percentages in the first year remained in the trial scheme also for the second and third year.

Date for the first and the second cuts

Date of the first cut in timothy has moved from 3-6 July during P1 to 23-26 June in periods P3 and P4 (Table 6). Since 1990 the first cut has come 0.2 days earlier each year on average. The second cut has changed by about the same number of days (about one week) earlier as the first cut, to the middle of August. Regrowth time from first cut to the second cut has been from 6 to 8 weeks, being on average 50, 43, 55 and 52 days in periods P1, P2, P3 and $\mathrm{P} 4$, respectively. Meadow fescue and tall fescue were cut at the same dates as timothy in periods P2, P3 and P4.

Table 6. Dates of the first and the second cuts of timothy in 1980-1989 (P1), 1990-1999 (P2), 2000-2009 (P3) and 2010-2017 (P4)

\begin{tabular}{lll}
\hline Period & Date for the 1st cut & Date for the 2nd cut \\
\hline P1 & 3-6 July & $21-25$ August \\
P2 & 28 June -2 July & $11-13$ August \\
P3 & $23-26$ June & $17-21$ August \\
P4 & $24-25$ June & $14-16$ August \\
\hline
\end{tabular}

Dry matter yields for timothy, meadow fescue and tall fescue

The dry matter yields (DMY) of the first and second cuts, and the total yield of timothy, meadow fescue and tall fescue in experiments in 1980-2017 are presented in Figures 5, 6 and 7 and in Table 7. Statistical analysis showed that the relationship between year and DMY were not always linear. Therefore, at the first stage the relationship was modeled using graphical methods by adding a smoothing spline curve to a scatter plot. Despite non-linearity, at the second stage tests for linear and quadratic polynomial trends for yields resulted in statistically significant effects for slope, and testing results for first, second and third year stands of timothy, meadow fescue and tall fescue are presented in the captions of Figures 5, 6 and 7. The DMY in the first and second cuts, and subsequently the total yields, increased markedly during the study periods. The annual average DMY increased in the first cut 


\section{AGRICULTURAL AND FOOD SCIENCE}

O. Niemeläinen et al. (2020) 29: 139-153

and in the second cut of timothy from period 1 to period 4 (Table 7). The total annual average DMY increased from $3128 \mathrm{~kg} \mathrm{ha}^{-1}$ in the period 1 to $9352 \mathrm{~kg} \mathrm{ha}^{-1}$ in the period 4 (Table 7).The change in DMY was similar for all studied species and for all three age categories of stands. The spline interpolation yield lines for 1, 2 and 3 year old stands of timothy, meadow fescue and tall fescue are presented in the Figures 5, 6 and 7 with statistical test results.

In timothy the DMY of the $1^{\text {st }}$ year stands has been highest, followed by $2^{\text {nd }}$ and $3^{\text {rd }}$ year stands (Fig. 5).

a) Yield (kg DM ha-1)

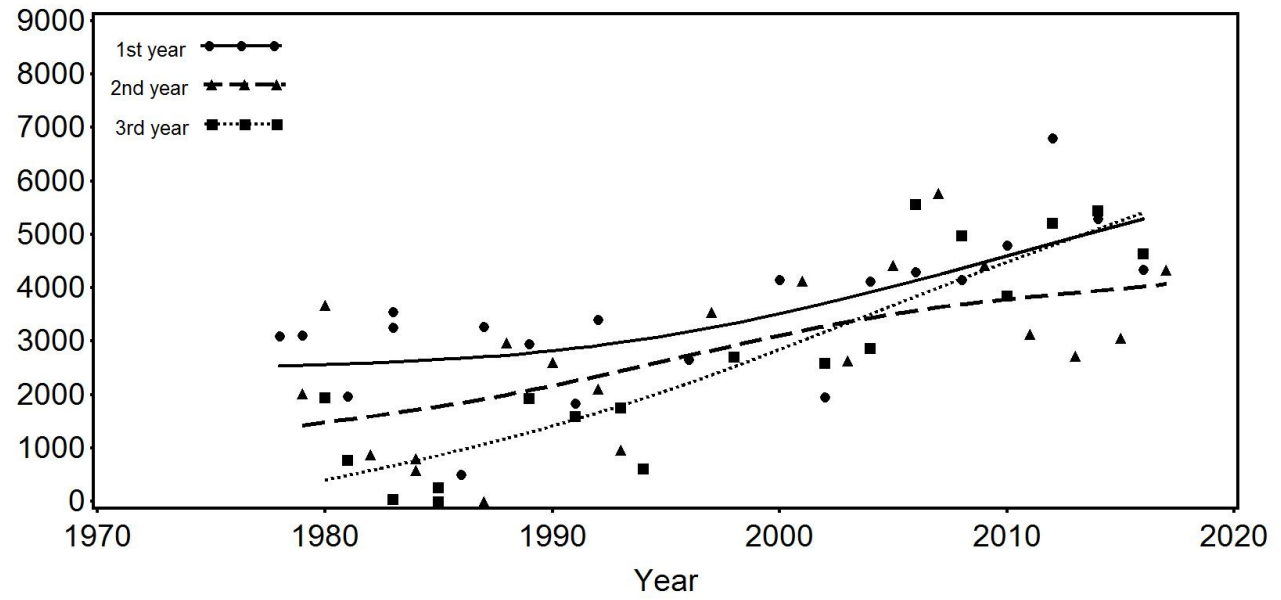

b) Yield (kg DM ha ${ }^{-1}$ )

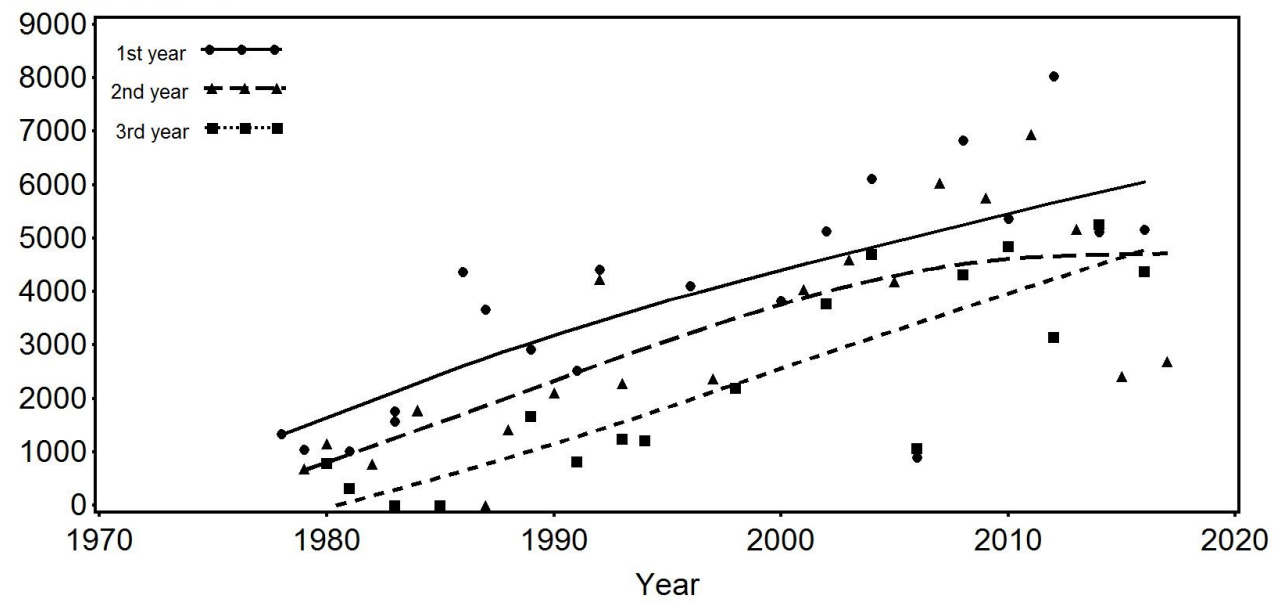

c) Yield (kg DM ha-1)

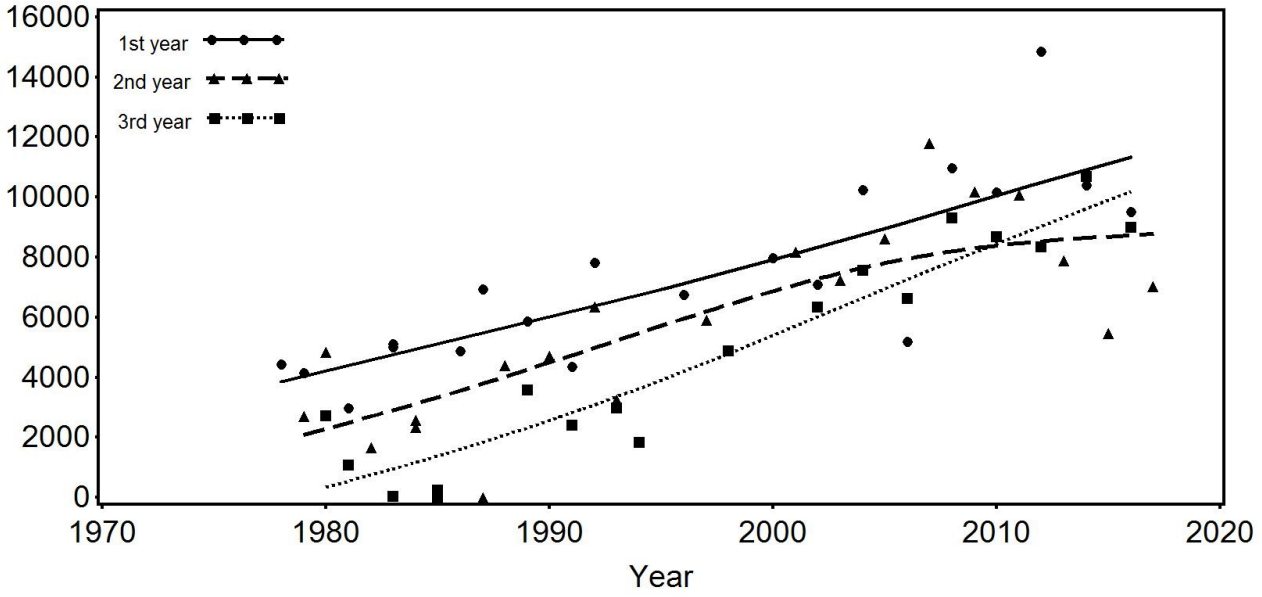

Fig. 5. Development of the dry matter yields (DMY) of the 1st (a) and 2nd cuts (b), and the total yield (c) of timothy during the study period $1978-2017 . \bullet-\cdots=1^{\text {st }}$ year stand, $\_-\mathbf{A}-\mathbf{k}=2^{\text {nd }}$ year stand,

$=3^{\text {rd }}$ year stand. Statistical significant increase was found in the first cut $(p<0.01)$, second cut $(p<0.001)$ and total yield $(p<0.001)$. 


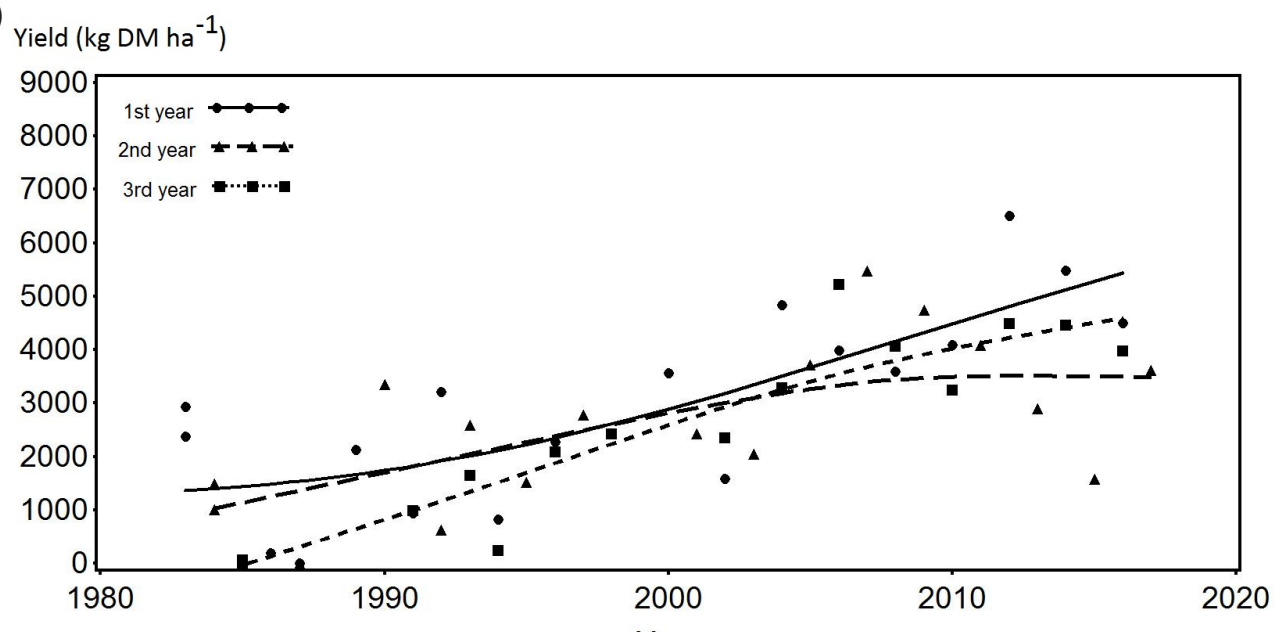

b)

Yield (kg DM ha ${ }^{-1}$ )

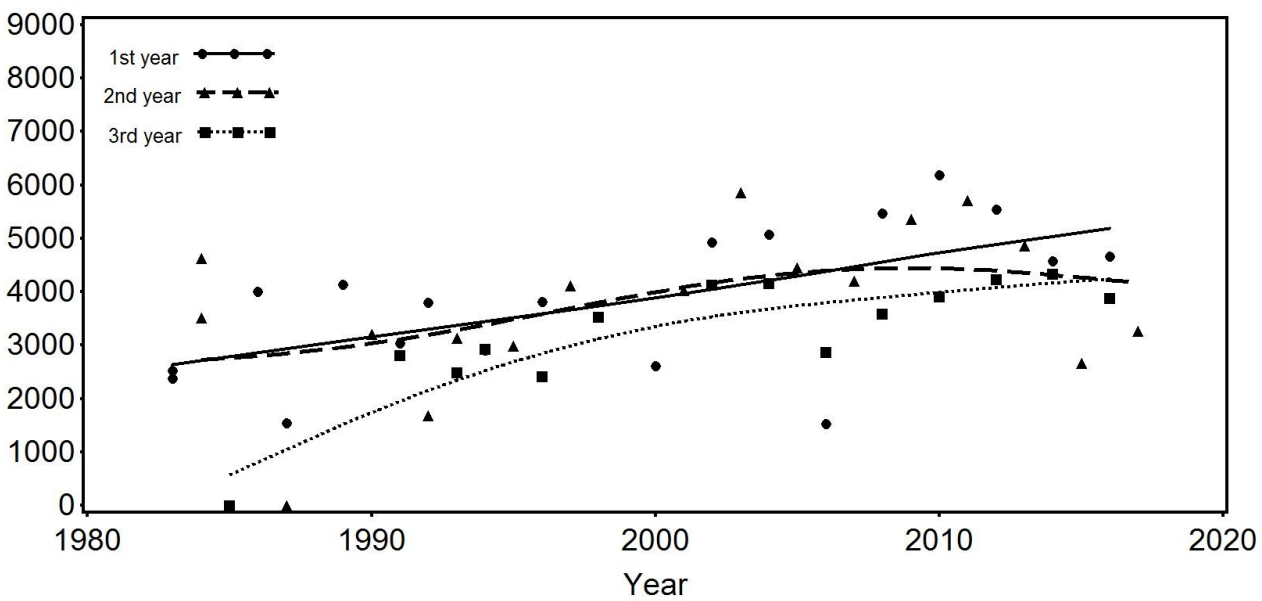

c)

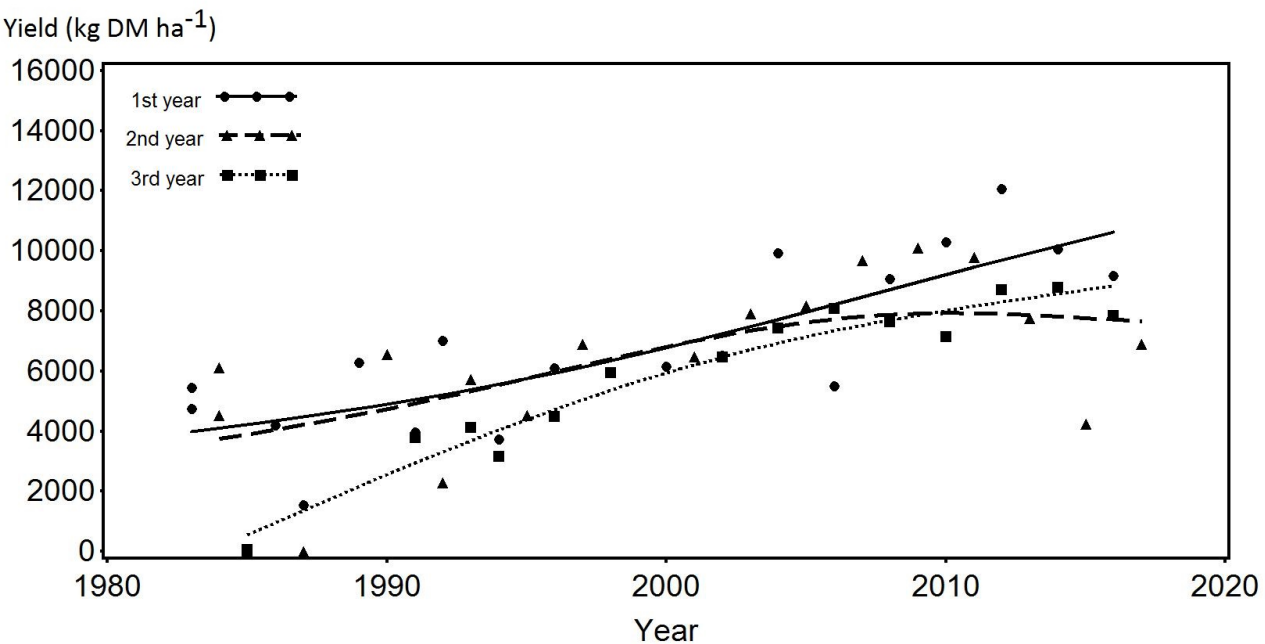

Fig. 6. Development of the dry matter yields (DMY) for the 1st (a) and 2nd cuts (b), and the total yield (c) of meadow fescue during the study period $1980-2017 . \cdots=1^{\text {st }}$ year stand, $\ldots \rightarrow-\boldsymbol{t}=2^{\text {nd }}$ year stand, -....... $=3^{\text {rd }}$ year stand. Statistical significant increase was found in the first cut ( $p<0.001$, except 2 nd year $p=0.01$ ), second cut $(p<0.001$, except 2 nd year $p=0.10)$ and total yield ( $p<0.001$, except 2 nd year $p=0.02$ )

Also in meadow fescue the increase in first cut and second cut yields and in total yield was substantial during the study period (Fig. 6). The annual DMY of meadow fescue was 3293, 4891, 7806 and $8572 \mathrm{~kg} \mathrm{ha}^{-1}$ in the periods P1-P4. In meadow fescue the first cut yielded 1022, 1828, 3642 and $4083 \mathrm{~kg} \mathrm{ha}^{-1}$, and the second cut 2272, 3063, 4164 and $4489 \mathrm{~kg} \mathrm{ha}^{-1}$, respectively in periods P1, P2, P3 and P4, respectively (Fig. 6). 


\section{AGRICULTURAL AND FOOD SCIENCE}

O. Niemeläinen et al. (2020) 29: 139-153

Tall fescue was included in trials since period P2. Its annual average total DMYs were 6488,8924 and $11062 \mathrm{~kg} \mathrm{ha}^{-1}$ in P2, P3 and P4, respectively. DMY of first cut of tall fescue was 2234, 3653 and 4422, and of second cut 4245, 5271 and $6640 \mathrm{~kg} \mathrm{ha}^{-1}$ in periods P2, P3 and P4, respectively. The effect of age of stand on yields of tall fescue differed from that for timothy and meadow fescue, as the DMY for tall fescue in the first year was not higher than the yield of second and third year stands (Fig. 7). Tall fescue establishes slowly and yield was smaller in the first year than in second and third year. Slow establishment reduces also the ratio of first:second cut in the first year.

a)

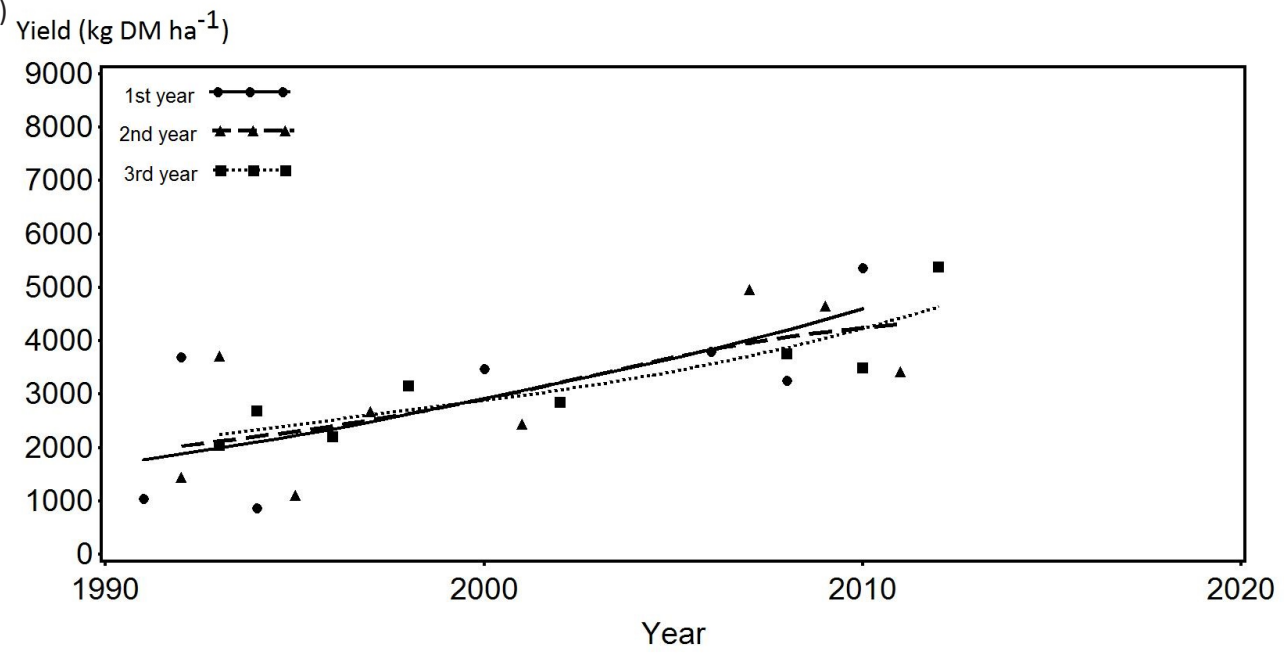

b) Yield (kg DM ha $\left.{ }^{-1}\right)$

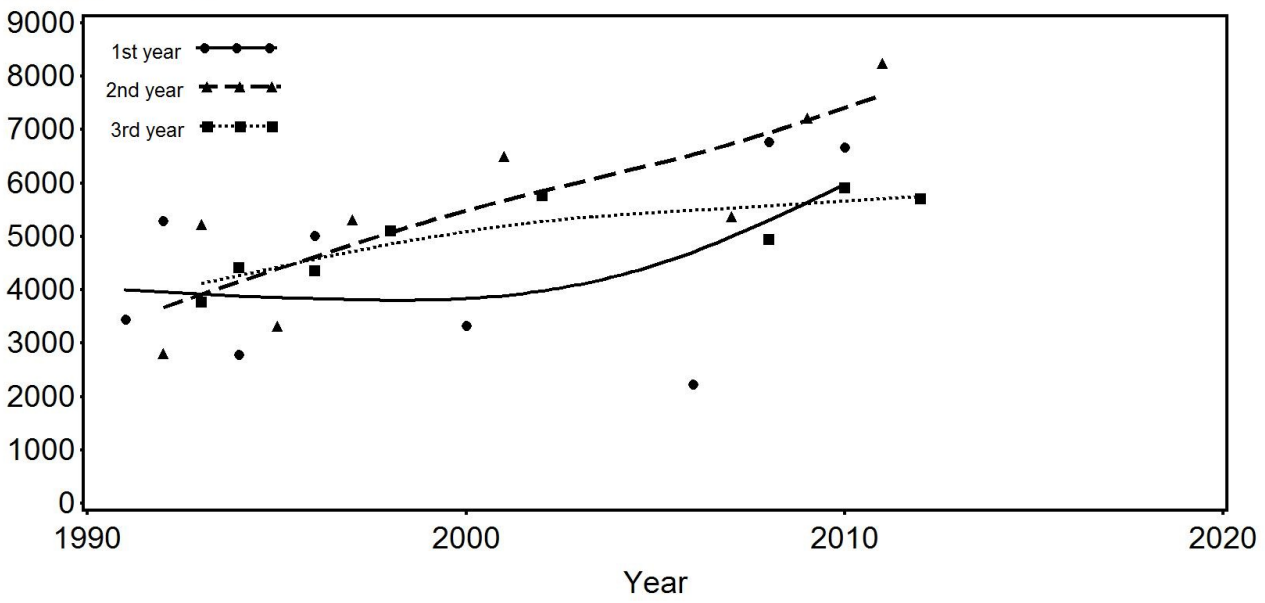

c) Yield (kg DM ha $\left.{ }^{-1}\right)$

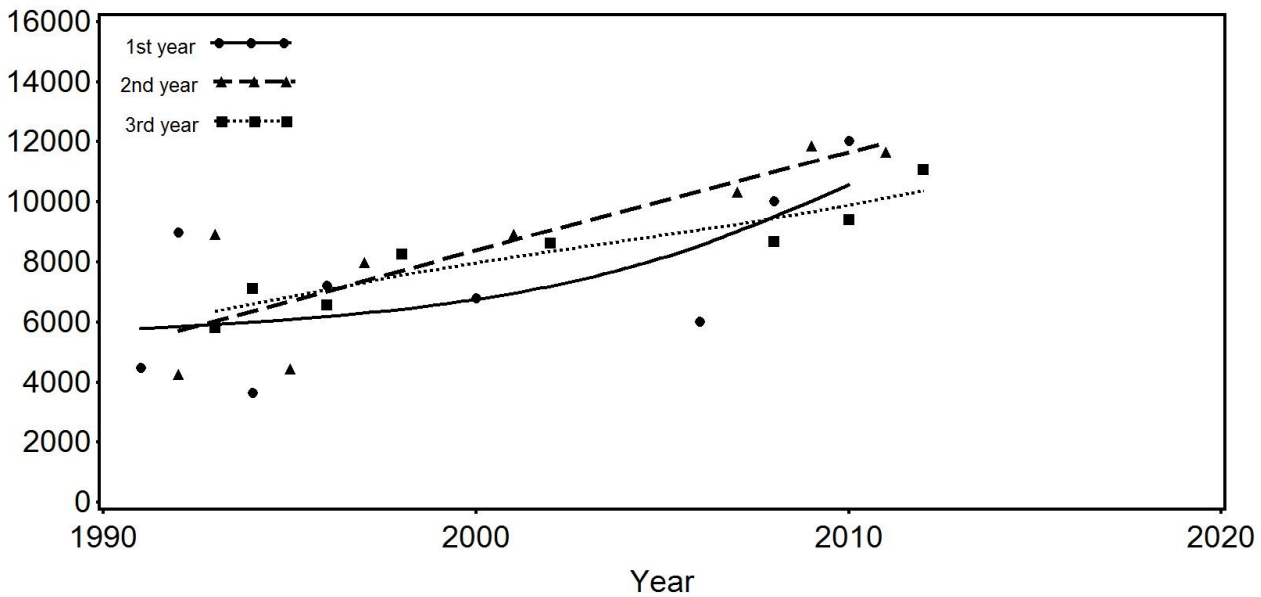

Fig. 7. Development of the dry matter yields (DMY) of the 1st (a) and 2nd cuts (b), and the total yield (c) of tall fescue during the study period 1990-2017. $\bullet-\cdots=1^{\text {st }}$ year stand, $₫ \rightarrow-\mathbf{-}=2^{\text {nd }}$ year stand, -...... $=3^{\text {rd }}$ year stand. Most of increases were statistically significant: the first cut $(p=0.04,0.02$ and $<0.01$ for 1st, 2nd and 3rd year stands, respectively), second cut ( $p=0.32,<0.01$ and 0.01 for 1 st, 2nd and 3 rd year stands, respectively) and total yield $(p=0.08,<0.01$ and $<0.01$ for 1 st, 2 nd and 3rd year stands, respectively). 


\section{AGRICULTURAL AND FOOD SCIENCE}

O. Niemeläinen et al. (2020) 29: 139-153

The annual yield profile differed among the studied species. In tall fescue the ratio of the first cut and the second cut yields ranged from 0.51 to 0.80 and in timothy from 0.99 to 1.74 in the different periods (Table 7). Meadow fescue performance was between those for timothy and tall fescue: for meadow fescue the ratio ranged from 0.48 to 1.01 (Table 7). For timothy the exceptionally high ratio during P1 (1.74), is influenced by harvesting timothy during the first years at the hay rather than silage stage.

Table 7. Yields $\left(\mathrm{kg} \mathrm{DM} \mathrm{ha}^{-1}\right)$ of timothy, meadow fescue and tall fescue first and second cuts and the ratio of the yields in the two cuts in 1980-1989 (P1), 1990-1999 (P2), 2000-2009 (P3) and 2010-2017 (P4). Results of first, second and third year stands area pooled.

\begin{tabular}{|c|c|c|c|c|}
\hline Period & Variable & Timothy** & Meadow fescue & Tall fescue \\
\hline P1 & $1^{\text {st }}$ cut yield & 1792 & 1022 & \\
\hline P2 & $1^{\text {st }}$ cut yield & 2166 & 1828 & 2243 \\
\hline P3 & $1^{\text {st }}$ cut yield & 4008 & 3642 & 3653 \\
\hline P4 & $1^{\text {st }}$ cut yield & 4473 & 4083 & 4422 \\
\hline P1 & $2^{\text {nd }}$ cut yield & 1337 & 2272 & \\
\hline P2 & $2^{\text {nd }}$ cut yield & 2503 & 3063 & 4245 \\
\hline P3 & $2^{\text {nd }}$ cut yield & 4378 & 4164 & 5271 \\
\hline P4 & $2^{\text {nd }}$ cut yield & 4879 & 4489 & 6640 \\
\hline P1 & Total yield & 3128 & 3293 & \\
\hline P2 & Total yield & 4668 & 4891 & 6488 \\
\hline P3 & Total yield & 8385 & 7806 & 8924 \\
\hline P4 & Total yield & 9352 & 8572 & 11062 \\
\hline P1 & Ratio $1^{\text {st }}: 2^{\text {nd }}$ cut* & 1.74 & 0.48 & \\
\hline P2 & Ratio 1st:2nd cut* & 0.99 & 0.58 & 0.51 \\
\hline P3 & Ratio 1st:2nd cut* & 1.40 & 1.01 & 0.80 \\
\hline P4 & Ratio 1st:2nd cut* & 1.00 & 0.91 & 0.69 \\
\hline
\end{tabular}

${ }^{*}$ The ratio $1^{\text {st }}: 2^{\text {nd }}$ cut is calculated from original yield results - not from the mean yields. ${ }^{* *}$ In timothy three results from years 1978 and 1979 are included in the data outside P1.

\section{Discussion \\ Changes in climate}

Changes in climate are predicted to be more rapid in the northern areas than global averages suggest (IPCC 2013, Mikkonen et al. 2015). Table 8 presents the calculated past and estimated future averages for climate variables during the growing season and winter in Rovaniemi for the periods 1971-2000 ("1986"), 2010-2039 ("2025") and 2040-2069 ("2055"). The variables for the future are calculated from weather data according to the RCP4.5 climate change scenario, provided by the FMI (Ruosteenoja et al. 2020). The $T_{\text {sums }}$ in our data for Apukka (Rovaniemi) have developed accurately according to the predictions by the RCP4.5 scenario (Table 8). The $T_{\text {sum }}$ increased from $880^{\circ} \mathrm{Cd}$ in P1 to $1036^{\circ} \mathrm{Cd}$ in P4. In the RCP4.5 scenario for Rovaniemi the values are 801 and 1008 'Cd for periods "1986" and "2025", respectively. However, the length of the growing season changed only little (from 143 to 145 days) between the study periods P1 and P4 (Table 3). The $156^{\circ} \mathrm{Cd}$ increase in the $\mathrm{T}_{\text {sum }}$ during the same time means that the growing season has become warmer in Apukka. The observed changes in rainfall during the growing seasons were small, in accordance with the RCP4.5 scenario, where the increase in rainfall sum during the growing season is due to a longer growing season, rather than an increase in daily precipitation. In the RCP4.5 data, the winter season is predicted to shorten from 188 to 172 days from "1986" to "2025", which is in accordance with the shortening of snow cover period in our study (Fig. 2). The frost sum decreased $461^{\circ} \mathrm{C}$ in Apukka during the 40 years from the 1980 s to the 2010 s, (from $-1850^{\circ} \mathrm{C}$ in $\mathrm{P} 1$ to $-1389^{\circ} \mathrm{C}$ in P4), in accordance with the predictions according to the RCP4.5 (altogether 476 decrease in the 50 year period from "1986" to "2025"). It can be concluded that the climate parameters in Apukka (Rovaniemi) have changed closely as predicted in the RCP4.5 scenario for 2010-2040 ("2025"). 
Table 8. Averages for some growing season and winter weather variable estimates for the period 1971-2000 ("1986") and for the periods 2010-2039 ("2025") and 2040-2069 ("2055") for Rovaniemi, according to RCP4.5. The variables are calculated from the data provided by the FMle (Ruosteenoja et al. 2020). $\mathrm{T}_{\text {sum }}\left({ }^{\circ} \mathrm{Cd}\right)=$ Temperature sum, degree-days, base temperature $+5^{\circ} \mathrm{C}$ )

\begin{tabular}{lccc}
\hline & 1971-2000; "1986" & 2010-2039; "2025" & 2040-2069; "2055" \\
\hline Start & 18 May & Growing season in Rovaniemi & 6 May \\
End & $22 \mathrm{Sept}$ & $10 \mathrm{May}$ & 3 Oct \\
Length (days) & 128 & $28 \mathrm{Sept}$ & 151 \\
Tsum ( ${ }^{\circ} \mathrm{Cd}$ ) & 801 & 142 & 1148 \\
Rainfall (mm) & 252 & 1008 & 307 \\
& & 287 & 30 Oct \\
Start & 16 Oct & Winter* in Rovaniemi & 6 Apr \\
End & $21 \mathrm{Apr}$ & 24 Oct & 158 \\
Length (days) & 188 & $13 \mathrm{Apr}$ & -914 \\
Frost sum ( $\left.{ }^{\circ} \mathrm{Cd}\right)$ & -1550 & 172 & 216 \\
Rainfall (mm) & 230 & -1074 & 222 \\
\hline
\end{tabular}

* Winter is specified as time when daily mean temperature is below $0^{\circ} \mathrm{C}$.

\section{Performance of timothy, meadow fescue and tall fescue}

Our yield data from Rovaniemi show marked increase in dry matter yields from 1980 to 2017 for timothy and meadow fescue. Predictions for climate change indicate increases in yields of agricultural crops in northern conditions (Peltonen-Sainio et al. 2009, Höglind et al. 2013, Jing et al. 2014, Persson and Höglind 2014, Ergon et al. 2017). Höglind et al. (2013) used an ensemble of 15 global climate models to assess uncertainties in impacts of climate change on grass production. In their study the yield increase in timothy in northern Europe from the baseline scenario (from 1960 to 1990) to near-future scenario (2040-2065) was, on average, 11\% for non-irrigated and $14 \%$ for irrigated conditions. The observed yield increase in Rovaniemi, in our study, was higher - from 3128, 4668, 8385 to $9352 \mathrm{~kg} \mathrm{ha}^{-1}$ in the periods P1, P2, P3 and P4, respectively. In the study of Höglind et al. (2013), optimal overwintering was assumed. In their study the baseline yield for Rovaniemi was around $9000 \mathrm{~kg} \mathrm{DM} \mathrm{ha}^{-1}$, and the near-future scenario resulted in approximately $10000 \mathrm{~kg} \mathrm{DM} \mathrm{ha}^{-1}$ yield. The low mean yields in our study in periods $\mathrm{P} 1$ and $\mathrm{P} 2$ are likely due to low live ground cover percentages in the springs in $\mathrm{P} 1$ and $\mathrm{P} 2$.The procedure that the whole three-year-trial period was completed when LGC percentage was low in the first year increased the impact of low LGC percentage on yield. In the periods P3 and P4 low LGC percentages did not occur. The highest annual yields in the trials were around $8000 \mathrm{~kg} \mathrm{DM} \mathrm{ha}^{-1}$ in P1 and P2, and over $10000 \mathrm{~kg} \mathrm{DM} \mathrm{ha}^{-1}$ in P3 and P4 (Fig. 5), close to the predicted yields in Höglind et al. (2013). This suggests that the low yields in the P1 and P2 were mostly caused by low live ground cover in the spring. The observed increase in timothy and meadow fescue yields could arise from the joint effect of improved live ground cover percentage in spring and the increasing $\mathrm{T}_{\text {sums }}$ of the growing seasons from $\mathrm{P} 1$ to $\mathrm{P} 4$. The about $50 \mathrm{ppm}$ increase in the $\mathrm{CO}_{2}$ concentration during the study period (from about 340-350 ppm in the 1980's to about 390-405 ppm in the 2010's, https://www.co2.earth/ monthly-co2) may also have had an effect on the increase in the yield of the grasses, both through enhanced photosynthesis during the growing season and through better overwintering and stress tolerance resulting from an increased root system (Hakala and Mela 1996, Hakala et al. 1999).

Several factors may have resulted to the higher live ground cover in spring: milder winter conditions, less severe disease attacks and/or improved winter hardening conditions for plants. The selected statistical model separates the effect of environment and genotypes. This means that the possible effect of use of more resistant cultivars against overwintering diseases was taken into account in the analysis so that more resistant cultivars would not be the main reason to the yield increase. The snow cover period became shorter and the wintertime milder, as measured by frost sum during the study period. The study of Nissinen (1996), utilizing data from Apukka, suggested that a shorter snow cover period reduces the risk of winter damage caused by Sclerotinia borealis and by Typhula ishikariensis. Dalmansdottir et al. (2017) reported that climate change in the north may reduce freezing tolerance in grasses if acclimation takes place at higher temperatures, shorter day length and with lower irradiance. Rapacz et al. (2014) and Ergon et al. (2017) stated that the effect of climate change on plant winter survival in the Nordic region is difficult to predict as climate change effects on plants' stress levels and on winter pathogens are 


\section{AGRICULTURAL AND FOOD SCIENCE}

O. Niemeläinen et al. (2020) 29: 139-153

very complex. The Basic Grassland Model (BASGRA) also takes into account factors related to overwintering conditions in modeling timothy growth (Höglind et al. 2016). Calibration of the BASGRA model for Rovaniemi conditions would be highly valuable to understand the different mechanisms affecting the success in overwintering. However, the impact of diseases is not yet incorporated into the BASGRA model (Höglind et al. 2016). The Korhonen et al. (2018) study with BASGRA, Canadian timothy model CATIMO and the soil crop model STIC for timothy included results from Rovaniemi in 1999-2001 for a trial with fertilizer rates and harvesting schedule treatments, and the studied growth models gave rather similar yield predictions as the observed results. Winter damage in that trial was small ranging from $7 \%$ to $20 \%$ (Nissinen et al. 2010). Our results indicate that the overwintering of timothy and meadow fescue in Rovaniemi has most likely improved due to shorter snow cover period and adequate cold acclimation in the autumns.

\section{Challenges for management and choice of species}

Optimal cutting schedule and fertilizer application are important issues to be solved to benefit from the improved growing conditions in Lapland. However, the nitrogen fertilizer rates 80 and $100 \mathrm{~kg} \mathrm{~N} \mathrm{ha}^{-1}$ for both cuts for timothy - difference of $40 \mathrm{~kg} \mathrm{~N} \mathrm{ha}^{-1}$ in a season - in the study of Nissinen et al. (2010) resulted to relatively small differences in average yields in their study in years 1999-2001. The yield in the first and second cut was 4115 vs 4034 kg DM ha-1 and 3544 vs $3852 \mathrm{~kg} \mathrm{DM} \mathrm{ha}^{-1}$ at the 80 and $100 \mathrm{~N} \mathrm{~kg} \mathrm{ha}^{-1}$ fertilizer rates, respectively. The $20 \mathrm{~kg} \mathrm{ha}^{-1}$ higher nitrogen application rate from year 2001 of the study period is unlikely the major reason for the yield increase. In a study of Hakala and Mela (1996), harvesting the meadow fescue at a leaf area index of five increased the yield and cutting times, when meadow fescue was cultivated at temperatures simulating the future conditions with climate change $\left(3^{\circ} \mathrm{C}\right.$ higher than in 1990s) under field conditions. Without adapting the cutting schedule, the yield increase was not fully achieved due to self-shading in the dense stand. In the study of Nissinen and Hakkola (1995) in Apukka in 1988-1992 (representing the earliest period of our study), the highest annual DMYs for timothy and meadow fescue were obtained in a two-cut system (hay + regrowth), followed by silage harvest ( 2 or 3 cuts) and pasture (3 cuts).

The spring growth is very important for timothy in Lapland. In the study of Nissinen et al. (2010) the growth rate of the regrowth was less than half that of the primary growth. Timothy is the main grass species in northern locations, but an increased regrowth capacity is needed in a prolonged growing season (Helgadottir et al. 2014). This raises a question of alternatives to timothy with better regrowth ability. In our study the ratio of the first to second DMY was lowest for tall fescue, indicating a strong regrowth ability, as found earlier by Niemeläinen et al. (2001). Tall fescue produced a high total DMY (Table 7). The results show that tall fescue performed very well in Rovaniemi.

In earlier simulation studies in Troms $\varnothing$, Norway (Persson and Höglind 2014) and Canada (Jing et al. 2014), yield increases in a warmer future climate stem from increased number of cuts in a season. In both studies the DMY in the first cut was smaller in the future scenarios than in the baseline situation, although the total annual yield increased. Good results for tall fescue warrant further studies of tall fescue in practical production. However, the risk related to use of non-native species in a warmer climate was emphasized by $\emptyset$ strem et al. (2015) and Höglind et al. (2013), who mentioned that timothy is well adapted to the very variable climatic growing conditions in the north. Our results show increasing overwintering capacity in timothy, meadow fescue and tall fescue with decreasing time of snow cover and thereby less favorable conditions for winter pathogens (Nissinen 1996) in periods P3 and P4. In Norway, the study by Bjerke et al. (2015) showed that winters with extremely deep snow caused considerable problems in overwintering, but the most challenging conditions were icy, shallow snow conditions. In a warmer climate in the future in Rovaniemi, ice formation and frost tolerance may play a greater role in overwintering of grass crops than has been the case to date. Use of species mixtures, which is a common practice in grass production, is one way to improve resilience (Mäkinen et al. 2015). In the Nissinen and Hakkola (1995) study, the mixture of timothy and meadow fescue had less winter damage than either of the two species grown in pure stands in Rovaniemi.

Continuous sward monitoring would be beneficial to provide information how different management decision and choices of species do effect sward performance in the variable conditions in Lapland. Remote sensing methods to estimate ley yields (Viljanen et al. 2018, Ancin-Murguzur et al. 2019) could provide a tool for that. Research should follow closely areas where climate change is most rapid and effects are most apparent. 


\section{Conclusions}

Timothy, meadow fescue and tall fescue showed marked increases in dry matter yields since 1980 in Apukka Research Station, Rovaniemi.

The increase in $\mathrm{T}_{\text {sum }}$ during the growing seasons, together with the milder winters and higher live ground cover in the spring are likely reasons for the increasing yields from 1980 to the present.

Research should follow closely the areas where climate change effects are most rapid and apparent.

Monitoring condition of grass swards is important and data should be gathered from farm fields using remote sensing methods.

\section{Acknowledgements}

Organizers of the official variety tests are kindly acknowledged for providing data from Apukka trials for this study. We express our sincere thanks to the reviewers whose comments on the manuscript were valuable.

\section{References}

Ancin-Murguzur, F.J., Taff, G., Davids, C., Tømmervik, H., Mølmann, J. \& Jørgensen, M. 2019. Yield estimates by a two-step approach using hyperspectral methods in grasslands at high latitudes. Remote Sensing 11: 400. https://doi.org/10.3390/rs11040400

Bjerke, J.W., Tømmervik, H., Zielke, M. \& Jørgensen, M. 2015. Impacts of snow season on ground-ice accumulation, soil frost and primary productivity in a grassland of sub-Arctic Norway. Environmental Research Letters: 10. https://doi.org/10.1088/1748-9326/10/9/095007

Dalmannsdottir, S., Jørgensen, M., Rapacz, M., Østrem, L., Larsen, A., Rødven, R. \& Rognli, O.A. 2017. Cold acclimation in warmer extended autumns impairs freezing tolerance of perennial ryegrass (Lolium perenne) and timothy (Phleum pratense). Physiologia Plantarum 160: 266-281. https://doi.org/10.1111/ppl.12548

Ergon, Å., Seddaiu, G., Korhonen, P., Virkajärvi, P., Bellocchi, G., Jørgensen, M., Østrem, L., Reheul, D. \& Volaire, F. 2017. How can forage production in Nordic and Mediterranean Europe adapt to the challenges and opportunities arising from climate change? European Journal of Agronomy 92: 97-106. https://doi.org/10.1016/j.eja.2017.09.016

Hakala, K., Hannukkala, A.O., Huusela-Veistola, E., Jalli, M. \& Peltonen-Sainio, P. 2011. Pests and diseases in a changing climate: a major challenge for Finnish crop production. Agricultural and Food Science 20: 3-14. https://doi.org/10.2137/145960611795163042

Hakala, K., Heliö, R., Tuhkanen, E. \& Kaukoranta, T. 1999. Photosynthesis and Rubisco kinetics in spring wheat and meadow fescue under conditions of simulated climate change with elevated $\mathrm{CO}_{2}$ and increased temperatures. Agricultural and Food Science in Finland 8: 441-457. https://doi.org/10.23986/afsci.5640

Hakala, K. \& Mela, T. 1996. The effects of prolonged exposure to elevated temperatures and elevated $\mathrm{CO}_{2}$ levels on the growth, yield and dry matter partitioning of field-sown meadow fescue (Festuca pratensis, cv. Kalevi). Agricultural and Food Science in Finland 5: 285-298. https://doi.org/10.23986/afsci.72747

Helgadóttir, Á., Frankow-Lindberg, B.E., Seppänen, M., Søegaard, K. \& Østrem, L. 2014. European grasslands overview: Nordic region. Grassland Science in Europe 19: 15-28. https://www.europeangrassland.org/en/infos/printed-matter/proceedings.html

Höglind, M., Van Oijen, M., Cameron, D. \& Persson, T. 2016. Process-based simulation of growth and overwintering of grassland using the BASGRA model. Ecological Modelling 335: 1-15. https://doi.org/10.1016/j.ecolmodel.2016.04.024

Höglind, M., Thorsen, S. M. \& Semenov, M.A. 2013. Assessing uncertainties in impact of climate change on grass production in Northern Europe using ensembles of global climate models. Agricultural and Forest Meteorology 170: $103-113$. https://doi.org/10.1016/j.agrformet.2012.02.010

IPCC 2012. Managing the Risks of Extreme Events and Disasters to Advance Climate Change Adaptation. In: Field, C.B., Barros, V., Stocker, T.F., Qin, D., Dokken, D.J., Ebi, K.L., Mastrandrea, M.D., Mach, K.J., Plattner, G.-K., Allen, S.K., Tignor, M. \& Midgley, P.M. (eds.). A Special Report of Working Groups I and II of the Intergovernmental Panel on Climate Change. Cambridge University Press, Cambridge, UK, and New York, NY, USA. 582 p. https://www.ipcc.ch/site/assets/uploads/2018/03/SREX_Full_Report-1.pdf

IPCC 2013. Climate Change 2013: The Physical Science Basis. In: Stocker, T.F., Qin, D., Plattner, G.-K., Tignor, M., Allen, S.K., Boschung, J.,Nauels, A., Xia, Y., Bex, V. \& Midgley, P.M. (eds.). Contribution of Working Group I to the Fifth Assessment Report of the Intergovernmental Panel on Climate Change. Cambridge University Press, Cambridge, United Kingdom and New York, NY, USA. 1535 p. https://www.ipcc.ch/report/ar5/wg1/

IPCC 2018. Global warming of $1.5^{\circ} \mathrm{C}$. In: Masson-Delmotte, V., Zhai, P., Pörtner, H.-O., Roberts, D.,Skea, J., Shukla, P.R., Pirani, A., Moufouma-Okia, W., Péan, C., Pidcock, R., Connors, S., Matthews, J.B.R, Chen, Y., Zhou, X., Gomis, M.I., Lonnoy, E., Maycock, T., Tignor, M. \& Waterfield, T. (eds.). An IPCC Special Report on the impacts of global warming of $1.5^{\circ} \mathrm{C}$ above pre-industrial levels and related global greenhouse gas emission pathways, in the context of strengthening the global response to the threat of climate change, sustainable development, and efforts to eradicate poverty. https://www.ipcc.ch/sr15/

Jing, Q., Bélanger, G., Qian, B. \& Baron, V. 2014. Timothy yield and nutritive value with a three-harvest system under the projected future climate in Canada. Canadian Journal of Plant Science 94: 213-222. https://doi.org/10.4141/cjps2013-279 


\section{AGRICULTURAL AND FOOD SCIENCE}

O. Niemeläinen et al. (2020) 29: 139-153

Korhonen, P., Palosuo, T., Persson, T., Höglind, M., Jégo, G., Van Oijen, M., Gustavsson, A.-M., Bélanger, G. \& Virkajärvi, P. 2018 Modelling grass yields in northern climates - a comparison of three growth models for timothy. Field Crops Research $224: 37-47$. https://doi.org/10.1016/j.fcr.2018.04.014

Laine, A., Högnäsbacka, M., Niskanen, M., Ohralahti, K., Jauhiainen, L., Kaseva, J. \& Nikander, H. 2017. Virallisten lajikekokeiden tulokset 2009-2016. Results of the Official Variety Trials 2009-2016. Luonnonvara- ja biotalouden tutkimus 1/2017. 271 p. http://urn.fi/URN:ISBN:978-952-326-346-8

Mikkonen, S., Laine, M., Mäkelä, H.M., Gregow, H., Tuomenvirta, H., Lahtinen, M. \& Laaksonen, A. 2015. Trends in the average temperature in Finland, 1847-2013. Stochastic Environmental Research and Risk Assessment 29: 1521-1529. https://doi.org/10.1007/s00477-014-0992-2

Mäkinen, H., Kaseva, J., Virkajärvi, P. \& Kahiluoto, H. 2015. Managing resilience of forage crops to climate change through response diversity. Field Crops Research 183: 23-30. https://doi.org/10.1016/j.fcr.2015.07.006

Niemeläinen, O., Jauhiainen, L. \& Miettinen, E. 2001. Yield profile of tall fescue (Festuca arundinacea) in comparison with meadow fescue (F. pratensis) in Finland. Grass and Forage Science 56: 249-258. https://doi.org/10.1046/j.1365-2494.2001.00271.x

Nissinen, O. 1996. Analyses of climatic factors affecting snow mold injury in first-year timothy (Phleum pratense L.) with special reference to Sclerotinia borealis. Acta Universitatis Ouluensis. Scientiae rerum naturalium A289. 115 p.

Nissinen, O. \& Hakkola, H. 1995. Effects of plant species and harvesting system on grassland production in northern Finland. Agricultural Science in Finland 4: 479-494. https://doi.org/10.23986/afsci.72624

Nissinen, O., Kalliainen, P. \& Jauhiainen, L. 2010. Development of yield and nutritive value of timothy in primary growth and regrowth in northern growing conditions. Agricultural and Food Science 19: 252-268. https://doi.org/10.2137/145960610792912602

Peltonen-Sainio, P., Jauhiainen, L., Hakala, K. \& Ojanen, H. 2009. Climate change and prolongation of growing season: changes in regional potential for field crop production in Finland. Agricultural and Food Science 18: 171-190. https://doi.org/10.2137/145960609790059479

Persson, T. \& Höglind, M. 2014. Impact of climate change on harvest security and biomass yield of two timothy ley harvesting systems in Norway. Journal of Agricultural Science 152: 205-216. https://doi.org/10.1017/S0021859612001013

Porter, J.R., Xie, L., Challinor, A.J., Cochrane, K., Howden, S.M., Iqbal, M.M., Lobell, D.B. \& Travasso, M.I. 2014. Food security and food production systems. In: Field, C.B., Barros, V.R., Dokken, D.J., Mach, K.J., Mastrandrea, M.D., Bilir, T.E., Chatterjee, M., Ebi, K.L., Estrada, Y.O., Genova, R.C., Girma, B., Kissel, E.S., Levy, A.N., MacCracken, S., Mastrandrea, P.R. \& White, L.L. (eds.). Climate change 2014: impacts, adaptation, and vulnerability. Part A: global and sectoral aspects. Contribution of Working Group II to the Fifth Assessment Report of the Intergovernmental Panel on Climate Change. Cambridge, UK, and New York, USA, Cambridge University Press. p. 485-533.

Rapacz, M., Ergon, Å., Höglind, M., Jørgensen, M., Jurczyk, B., Østrem, L., Rognli, O.-A. \& Tronsmo, A.M. 2014. Overwintering of herbaceous plants in a changing climate. Still more questions than answers. Plant Science.

http://dx.doi.org/10.1016/j.plantsci.2014.05.009

Ruosteenoja, K., Markkanen, T. \& Räisänen, J. 2020. Thermal seasons in northern Europe in projected future climate. International Journal of Climatology 2020:1-19. https://doi.org/10.1002/joc.6466

Viljanen, N., Honkavaara, E., Näsi, R., Hakala, T.Y., Niemeläinen, O. \& Kaivosoja, J. 2018. A novel machine learning method for estimating biomass of grass swards using a photogrammetric canopy height model, images and vegetation indices captured by a drone. 2018. Agriculture 8: 70. https://doi.org/10.3390/agriculture8050070

Virallisten lajikekokeiden suoritusohjeet 2018. (Guidelines for carry out the official variety trials 2018). 123 p. (in Finnish). Mimeographed.

Watts, J. 2019. The end of the Arctic as we know it. The Guardian, 7 July 2019. Cited 16 August 2019.

https://www.theguardian.com/environment/2019/jun/07/oceans-demise-the-end-of-the-arctic-as-we-know-it.

Østrem, L., Rapacz, M., Larsen, A., Dalmannsdottir, S. \& Jørgensen, M. 2015. Influences of growth cessation and photoacclimation on winter survival of non-native Lolium-Festuca grasses in high-latitude regions. Environmental and Experimental Botany 111: 21-31. https://doi.org/10.1016/j.envexpbot.2014.10.008 